\title{
Pelviscapular dysplasia
}

INSERM

\section{Source}

INSERM. (1999). Orphanet: an online rare disease and orphan drug data base.

Pelviscapular dysplasia. ORPHA:93333

Pelviscapular dysplasia (Cousin syndrome) is characterized by the association of pelviscapular dysplasia with epiphyseal abnormalities, congenital dwarfism and facial dysmorphism. 